\title{
Mutual Issues of Bioprinting and Stem Cell Technologies in Neural Tissue Repair
}

\author{
Shanko Yuri ${ }^{1}$, Krivenchuk Dmitry ${ }^{2}$, Zamaro Alexandraa ${ }^{1,2}$, Koulchitsky Stanislav ${ }^{3}$, Navitskaya Valeria $^{1}$ \\ and Kulchitsky Vladimir ${ }^{1,2 *}$ \\ ${ }^{1}$ Republican Scientific and Practical Center of Neurology and Neurosurgery, Minsk, Belarus \\ ${ }^{2}$ Brain Center, Institute of Physiology, National Academy of Sciences, Minsk, Belarus \\ ${ }^{3}$ Liege University, Belgium \\ *Corresponding author: Vladimir Kulchitsky, Scientific Director, Institute of Physiology, National Academy of Sciences of Belarus, \\ Republican Scientific and Practical Center of Neurology and Neurosurgery, 28 Akademicheskaya Street, Minsk 220072, Belarus
}

\begin{tabular}{|c|c|}
\hline ARTICLE INFO & ABSTRACT \\
\hline Received: 慧 April 03, 2019 & Bioprinting technologies and cell technologies are being developed to correct and / or restore \\
\hline Published: 櫘 April 08, 2019 & $\begin{array}{l}\text { the activity of various functional systems of the body. The paper focuses on the effective restoration } \\
\text { of the functional unity of the nervous system and the whole body after injury. At the same time, the }\end{array}$ \\
\hline $\begin{array}{l}\text { Citation: Shanko Y, Krivenchuk D, } \\
\text { Zamaro A, Koulchitsky S, Kulchitsky }\end{array}$ & $\begin{array}{l}\text { the nervous tissue. The article draws attention to the unresolved methodological issues of bioprinting } \\
\text { and cellular technologies, the main purpose of which is the most effective and correct recovery of } \\
\text { damaged brain functions. }\end{array}$ \\
\hline
\end{tabular}

$\mathrm{V}$, et al, Mutual Issues of Bioprinting and Stem Cell Technologies in Neural Tissue Repair. Biomed J Sci \& Tech Res

Abbreviations: $\mathrm{Cl}^{-}$: Chloride Ion; GABA: Gamma-Aminobutyric Acid; MSCs: Mesenchimal Stem Cells; SCs: Stem Cells

16(5)-2019. BJSTR. MS.ID.002918.

\section{Introduction}

That sad-strict spirit then did not dissemble - The one who called himself the morning star - When uttered he: "Fear not the highest's bar, - Just eat forbidden fruit, and you'll the gods resemble" (N.Gumilev). The depressing statistical information about the high mortality of patients with brain diseases and the lack of effectiveness of classical therapies is an incentive to develop new methods of prevention, therapy and rehabilitation of patients in neurology and neurosurgery $[1,2]$. The authors of the article focused on cellular technologies [3-6] as additional recovery measures in the early stages of the development and progression of brain diseases. In contrast to the popular systemic injections of stem cells (SCs), which are distributed via bloodstream throughout the body [3-6], emphasis is placed on the perineural migration of mesenchymal stem cells (MSCs) along the cranial nerves to the destruction site [712]. This tactic of targeted somatotopic distribution of autologous MSCs in those damaged areas of the brain, in which reparative processes are supposed to be activated, is aimed at improving the efficiency of classical therapy for patients with strokes and brain injuries $[7,9,10,12]$. It is noteworthy that the bioprinting technology pursues a similar goal when it is planned to implant a bioprinting substrate, including neural networks, into the damaged brain area [13].

\section{Neural Tissue Reconstruction using Bioprinting and Cell Technologies}

When cellular technologies are used, MSCs begin to activate reparative processes in the damaged area of the brain with the help of various signaling molecules. The basis for the activation of reparative processes are endogenous SCs, which, under the influence of signaling molecules from MSCs, begin to move from the periventricular spaces, olfactory bulbs and the hippocampus to the damaged areas of the brain. Externally introduced MSCs and endogenous SCs together activate immunosuppressive processes, which are accompanied by a weakening of immune responses during the development of destructive processes in the brain [1-6]. Neurotrophic factors that are secreted from MSCs and endogenous SCs, weaken the processes of neuronal degeneration and activate reparative processes [1-6]. In the case of spheroids and other elements of bioprinting, SCs, which are contained in these substrates, also begin to activate endogenous reparative processes. However, comparing effectiveness of restoration processes when 
applying these two technologies, a number of differences draw attention.

In the bioprinting substrate there is no network of blood vessels and full-fledged elements of the intercellular matrix. It takes time for these biological components to appear in the damaged area of the brain. So, when using cellular technologies and a bioprinting substrate, the question of the phased restoration of the necessary elements of the mesoderm in the damaged areas of the brain remains unresolved. In particular, we are talking about microglia, the functional role of which lies not only in the manifestation of immunocompetent properties, but also in activating the growth of processes of neurons and other processes. Another unresolved issue of these two promising technologies is the restoration of the balance of neurotransmitters in a destroyed part of the brain. For example, let's pay attention to two key neurotransmitters - Gammaaminobutyric acid (GABA) and glutamate, the receptors for which are contained on the membrane $40 \%$ of brain neurons [14]. GABA and glutamate are interconnected in a chain of neurochemical reactions.

Specifically, GABA is formed as a result of glutamate decarboxylation and controls the formation of neurite synapses and the migration of neurons from the periventricular zone to the cortical regions [14]. There is another important nuance. At the early stages of ontogenesis, GABA is known to be an excitatory neurotransmitter [14], since it controls the release of an increased amount of intracellular chloride ion $\left(\mathrm{Cl}^{-}\right)$from the cytoplasm of neurons to the outside [14]. This pattern is observed in a wide range of brain structures and animal species, which indicates its origin and preservation throughout evolution. Consequently, at the stages of formation of new neural networks using SCs or using bioprinting technologies, it is advisable to take into account that immature neurons with a high level of $\mathrm{Cl}^{-}$and the natural stimulating effect of GABA are able to show increased convulsive activity characteristic of pathological conditions. But this activity of GABAergic neurons is typical of the immature brain [14]. Therefore, it is logical to develop cellular technologies and bioprinting techniques simultaneously in space and time, applying 4D, 5D, 6D innovations for harmonious interaction of neural network cells with each other, taking into account afferent and efferent electrical signals, as well as various signaling molecules.

\section{Conclusion}

The state of recovery of nervous tissue functions after a neurodestructive process is to some extent associated with an early period of ontogenesis, when newly formed neurons containing GABA are not inhibitory, but stimulating. It is clear that such problematic issues are associated in damaged areas of the brain with both the reparative capabilities of cellular technologies and the adequate implantation of bioprinting substrates. Another common problem for these two technologies is the complexity of the formation of the interaction of newly formed neural networks in the area of brain destruction with the surrounding neural networks. In addition to the neurotrophic factors in both cases, the necessary conditions for the formation of not only a single neuronal network, but also the inclusion of the local microvascular network in the intracerebral network of blood vessels, the unification of the extracellular matrix in the destructive brain regions with the surrounding biological tissues, harmonious interaction of newly formed synaptic contacts.

For example, the absence of such interaction at the level of a synapse that secretes glutamate can, without recapturing glutamate by glial elements, lead to the overstimulation of the postsynaptic membrane and the death of a nerve cell. Paradoxically, at the initial stages of the formation of neural networks, similar neuronal cell death develops when the presynaptic GABA membrane is overexcited and not glutamate, which naturally ends with the death of nerve cells [14]. Thus, the efficiency of functioning of neural networks recreated using bioprinting technologies and/or cellular technologies depends on the consolidation of the ability of nerve cells to interact not only at the neuronal level, but also at the level of macro- and microglia, the intercellular matrix, the network blood vessels, cerebrospinal fluid, neurotrophic factors and a complex of intra-and extracellular signaling molecules $[15,16]$.

\section{Acknowledgement}

This pooled analysis was funded by 000 "Synergy", and by innovative fund of Brest Regional Executive Committee (20172019).

\section{Conflict of Interest}

All listed authors concur with the submission of the manuscript; all authors have approved the final version. The authors have no financial or personal conflicts of interest.

\section{References}

1. Chen S, Singh RJ, Kamal N, Hill MD (2018) Improving care for acute inhospital ischemic strokes-A narrative review. Int J Stroke 13(9): 905912.

2. Muir KW (2017) Clinical trial design for stem cell therapies in stroke: What have we learned? Neurochem Int 106: 108-113.

3. Kalladka D, Sinden J, Pollock K, Haig C, Mc Lean J, et al. (2016) Human neural stem cells in patients with chronic ischaemic stroke (PISCES): a phase 1, first-in-man study. Lancet 388(10046): 787-796.

4. Rossetti T, Nicholls F, Modo M (2016) Intracerebral Cell Implantation: Preparation and Characterization of Cell Suspensions. Cell Transplant 25(4): 645-664

5. Kokaia Z, Darsalia V (2018) Human Neural Stem Cells for Ischemic Stroke Treatment. Results Probl Cell Differ 66: 249-263.

6. Moritz CT (2018) Now is the Critical Time for Engineered Neuroplasticity. Neurotherapeutics 15(3): 628-634.

7. Kulchitsky V, Zamaro A, Shanko Y, Koulchitsky S (2018) Prospects of Perineural Implantation of Stem Cells in Recovery of Neural Networks' Functions in Brain Diseases. Biomed J Sci \& Tech Res 10(3): 1-4.

8. Shanko Y, Zamaro A, Takalchik Stukach Y, Koulchitsky S, Pashkevich S, et al. (2018) Mechanisms of Neural Network Structures Recovery in Brain Trauma. Biomed J Sci \& Tech Res 7(5): 1-2.

9. Shanko Y, Navitskaya V, Zamaro A, Krivenko S, Zafranskaya M, et 
al. (2018) Prospects of Perineural Administration of Autologous Mesenchymal Stem Cells of Adipose Tissue in Patients with Cerebral Infarction. Biomed J Sci\&Tech Res 10(1): 1-3.

10. Shanko Y, Navitskaya V, Zamaro A, Zafranskaya M, Krivenko S, et al (2018) Somatotopic principle of perineural implantation of stem cells in patients with brain injuries. J Neurol Stroke 8(5): 259-261.

11. Kulchitsky V, Zamaro A, Pashkevich S, Sushko T, Koulchitsky S (2018) Nasolacrimal way of stem cells implantation. J Neurol Stroke 8(2): 110111.

12. Kulchitsky V, Zamaro A, Shanko Y, Koulchitsky S (2018) Positive and negative aspects of cell technologies in cerebral diseases. J Neurol Stroke 8(2): 87-88.

\section{ISSN: 2574-1241}

DOI: 10.26717/BJSTR.2019.16.002918

Kulchitsky Vladimir. Biomed J Sci \& Tech Res

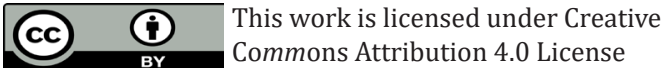

Submission Link: https://biomedres.us/submit-manuscript.php
13. Zamaro A, Krivenchuk D, Denisov A, Koulchitsky S, Kulchitsky V (2018) Topical Issues of Bioprinting Technology. Biomed J Sci \& Tech Res 12(1): 1-3.

14. Ben-Ari Y (2014) The GABA excitatory/inhibitory developmental sequence: a personal journey. Neuroscience 279: 187-219.

15. Davydov MV, Osipov AN, Kilin SY, Kulchitsky VA (2018) Neural Network Structures: Current and Future States. OSTIS, pp. 259-264.

16. Reimann MW, Horlemann AL, Ramaswamy S Muller EB, Markram H (2017) Morphological Diversity Strongly Constrains Synaptic Connectivity and Plasticity. Cereb Cortex 27(9): 4570-4585.

$\begin{array}{ll}\text { BIOMEDICAL } & \text { Assets of Publishing with us } \\ \text { RESEARCHES } & \text { - Global archiving of articles } \\ \text { - Immediate, unrestricted online access } & \text { - Rigorous Peer Review Process } \\ & \text { - Authors Retain Copyrights } \\ & \end{array}$

